\title{
A SINGLE NUCLEOTIDE POLYMORPHISM C/T-13910 AND CONSUMPTION OF DAIRY PRODUCTS IN UZBEK POPULATION
}

Sharaf Kasimov ${ }^{1}$, Gulchehra Nazarova², Dania Kasimova ${ }^{3}$, Zebo Yunusova ${ }^{4}$, Movluda Rakhmatova ${ }^{5}$

\section{HOW TO CITE THIS ARTICLE:}

Sharaf Kasimov, Gulchehra Nazarova, Dania Kasimova, Zebo Yunusova, Movluda Rakhmatova. "A Single Nucleotide Polymorphism C/T-13910 and Consumption of Dairy Products in Uzbek Population". Journal of Evolution of Medical and Dental Sciences 2015; Vol. 4, Issue 86, October 26; Page: 15042-15050,

DOI: $10.14260 /$ jemds/2015/2134

ABSTRACT: AIM: To determine the relationship between C/C-13910 genotyping and consumption of dairy products in an Uzbek population and to study the incidence of gastrointestinal symptoms for dairy products in the LNP C/C-13910 carriers. METHODS: 100 Uzbeks were examined for nucleotide polymorphisms by polymerase chain reaction/restriction fragment length polymorphism. Dairy tolerance was analyzed by a questionnaire, developed to assess dyspepsia after milk and dairy consumption. RESULTS: The genetic allele variant C/C-13910, the marker of lactase non-persistence, was found in $81 \%$ of cases in the Uzbek population. In 19\% of the subjects, the genotype C/T-13910 was found. No statistically significant relationship was found between the lactase deficiency genotype and consumption of dairy products $(p>0,05)$. The majority of the participants with the genotype C/C-13910 were reported to consume dairy products every day or several times in week. Among carriers of genotype LNP gastrointestinal symptoms, when consuming dairy products, do not occur more often than in those with genotype LP ( $p>0.05)$. CONCLUSION: Despite the high prevalence of lactase deficiency in the Uzbek population, Uzbeks tolerate dairy products well and regularly consume them. Regular consumption of fermented milk products in the diet of the Uzbek population is likely to compensate for the rare use of milk and helps with the intake of calcium and other nutrients contained in milk.

KEYWORDS: Lactase non-persistence, dairy consumption, Uzbek population.

INTRODUCTION: Adult type hypolactasia develops due to decreased activity of the enzyme lactase phlorizin hydrolase and stops its synthesis in mammals after the weaning period. Lactase breaks down milk disaccharide lactose into glucose and galactose.[1-3]

A single nucleotide polymorphism (SNP) located $13.9 \mathrm{~kb}$ upstream of the lactase gene, is known as LCTC>T-13910. Termination of synthesis of lactase in the ciliated epithelium of the mucous membrane of the small intestine is caused by decrease transcription of gene LCT, encoding the enzyme lactase. Genetic marker C/T-13910 DNA region in intron 13 of the gene MCM6, located near the gene LCT, where cytosine(C) is replaced by thymine(T) at position -13 910.

As a result of such a substitution the activity of gene transcription LCT changes. Carriers of allele genotype C/C-13910 are characterized by a decrease in the level of lactase in adulthood. Lactase deficiency is inherited as an autosomal recessive trait.[4-6]

Lactose malabsorbtion manifests as gastrointestinal symptoms (Diarrhea, bloating, abdominal pain, etc.). Carriers of allele genotype $\mathrm{C} / \mathrm{T}$ and $\mathrm{T} / \mathrm{T}-13910$ can digest lactose, and this ability is not lost with time.[7-9]

LCT gene mutation associated with nucleotide polymorphism C/T-13910 occurred about 500010,000 years ago, during the development of agriculture and animal domestication. ${ }^{[5,6]}$ 
Hypotheses about the LCT gene mutation considered that good tolerance of lactose gave carriers of the gene advantages in the struggle for survival and allowed to spread widely.[10]

The prevalence of primary lactose maldigestion is 3-5\% in Scandinavia, $17 \%$ in Finland, 5-15\% in Great Britain, 15\% in Germany, 15-20\% in Austria, 17\% in northern France, 65\% in southern France, $20-70 \%$ in Italy, $55 \%$ in the Balkans, $70-90 \%$ in Africa(Exceptions: Bedouins, 25\%; Tuareg, 13\%; Fulani, 22\%), 80\% in Central Asia, 90-100\% in Eastern Asia, 30\% in northern India, $70 \%$ in southern India, $15 \%$ in North American whites, $80 \%$ in North American blacks, 53\% in North American Hispanics, and 65-75\% in South America.[11]

In the population of indigenous peoples in Central Asia, most milk is consumed in small quantities and milk is mainly given to children. Among dairy products, the most well-known and frequently used are: syuzma (chakka), yogurt (katik), dry milk product (kurt), fermented mare's milk (kumis) and others. Uzbeks often use milk products such as katik (yogurt) and syuzma (chakka). Syuzma is made by removing whey from katik. Katik is poured into a cotton bag and hung. Whey seeps through the fabric, leaving curd in the bag that resembles cottage cheese.

The frequent consumption of milk products among Uzbeks forced us to study the relationship between C/C-13910 genotyping and consumption of dairy product in an Uzbek population and to determine the frequency of gastrointestinal symptoms when consuming dairy products.

MATERIALS AND METHODS: The study was carried out in the population group attached to the "Fayzilobod" Rural General Practice (RGP) in the Asaka District of the Andijan province of Uzbekistan. A simple random sample $(n=120)$ of the population aged 16 to 70 years was drawn from the list of people permanently registered in the area $(2,771$ people aged 16 to 70$)$.

A representative sample of the populations was studied using the medical services lists of RGP "Fayziobod". Several persons in the representative sample did not take part in the study for unrelated reasons. They were replaced by others from a randomized list, according to the general procedure for choosing replacements.

The group of Uzbeks studied effectively met the requirements arising from the goals and objectives of the study. The study was approved by the National Ethics Committee under the Ministry of Health of Uzbekistan. An informed voluntary written consent was obtained from the subjects who participated in the study. A questionnaire developed by the author consisted of questions concerning the individual's health, personal data (ethnicity, including ethnicities going back three ancestral generations), symptoms of milk and dairy product intolerance, and attitude to milk and dairy consumption.

A blood sample was drawn from each participant for lactase-deficiency genotyping. Blood sample collection and transportation to the laboratory were performed according to a protocol, approved by the Centre for Medical Genetics of the Institute of Biochemistry in the Academy of Sciences, on labeling, storing and delivering blood. DNA was isolated using standard procedures.

Genotyping One-millilitre blood samples were obtained from the cubital vein of each participant. DNA was isolated from this venous blood using the Diatom ${ }^{\text {TM }}$ DNA Prep 200 DNA purification kit (Invitrogen, USA) according to the manufactureres protocol.

The presence of genomic DNA was verified by $0.9 \%$ agarose gel electrophoresis with ethidium bromide, followed by visualisation under UV light on a Wise DOC gel documentation device. SNP identification was achieved by polymerase chain reaction/restriction fragment length polymorphism (PCR/RFLP). To identify alleles of the SNP C/T-13910, a fragment of $201 \mathrm{bp}$ was first amplified using 


\section{ORIGINAL ARTICLE}

the primers: 5'-GCTGGCAATACAGATAAGATAATGGA-3' and

CTGCTTTGGTTGAAGCGAAGAT-3'. Polymerase chain reaction (PCR) amplifications were carried out in 0.2-mL PCR tubes, using a GenePack PCR Core kit (Invitrogen) with lyophilised components.

Each tube contained 1.5 units of Taq DNA polymerase, $10 \mathrm{mM}$ of Tris- $\mathrm{HCl}(\mathrm{pH} 9), 50 \mathrm{mM}$ of $\mathrm{KCl}$, $1.5 \mathrm{mM}$ of $\mathrm{MgCl} 2$ and $200 \mathrm{mM}$ of each dNTP. $2.5 \mu \mathrm{L}$ of each primer (10 $\mu \mathrm{M}$ solution), $10 \mu \mathrm{L}$ of the PCR diluent and $5 \mu \mathrm{L}$ of DNA were added to each tube and PCR was performed using an Applied Biosystems GeneAmp 9700 PCR thermal cycler system.

The PCR cycle conditions were as follows: an initial round of denaturation at $95^{\circ} \mathrm{C}$, then 35 cycles at $95^{\circ} \mathrm{C}$ for 60 seconds, $59^{\circ} \mathrm{C}$ for 60 seconds, $72^{\circ} \mathrm{C}$ for 60 seconds, and a final extension of $72^{\circ} \mathrm{C}$ for 1 minute. PCR products were digested with $5 \mathrm{u}$ HinfI (Fermentas). Amplification and digestion products were run on an $8 \%$ polyacrylamide gel and visualised by ethidium bromide staining.

Samples that only presented a 201-bp(C) fragment or a 177-bp (T) fragment were interpreted as CC and TT genotype, respectively, while those that presented two fragments of $201 \mathrm{bp}$ and $177 \mathrm{bp}$ were interpreted as the CT genotype. The association between dairy products consumption/intolerance symptoms and genotype variants was tested using Fisher's exact test.

RESULTS: From this random sample group of 120 subjects, one hundred (83.3\%) responded to the questionnaire designed to reveal milk and dairy intolerance. There were 63 males and 37 females. Age distribution was as follows: 46 participants in the age group 16-29 years, 33 in the age group 30 49 years, and 21 in age group 50-70 years. All study subjects were Uzbeks (At least three maternal and paternal grandparents reported to be Uzbeks).

The following chronic diseases were noted among the participants in the study: Ischemic heart disease-2, arterial hypertension-4, stomach and duodenal ulcer-1, irritable bowel syndrome-2 iron-deficiency anemia not associated with nutritional factors-1, allergies (hay fever)-1, Glaucoma -1, pyelonephritis-1.

Out of the 100 subjects $81 \%$ had the genotype characteristic to lactase non-persistence(C/C). We found only two variants of nucleotide polymorphism(C/T-13910 and C/C-13910). The T/T-13910 genotype was not found in any of the cases (Table I).

Consumption of dairy products among the Uzbek population was frequent. Most Uzbeks eat dairy products every day or several times a week. These dairy products are mostly sour milk and syuzma.

The results of the questionnaire on the frequency of consumption of dairy products, comparing the intake of dairy products with the different variants of the genotype C/T-13910, are shown in Table II.

Six people felt abdominal discomfort after consuming dairy products. All of them were carriers of genotype $\mathrm{C} / \mathrm{C}-13910$. The subjects who reported symptoms after consuming dairy products complained of abdominal bloating and diarrhea.

DISCUSSION: This population-based study of the prevalence of hypolactasia was conducted in a remote region, far from the major administrative centers of the area where this isolated population of the ethnic Uzbek live. To establish the existence of the syndrome arising from adult type hypolactasia we used the original questionnaire, which covered ethnic identification, the presence of chronic diseases, anthropometry and tolerance to the use of milk and dairy products.

All participants of the study who had diseases of the stomach and intestines were milk tolerant. This indicates that they did not suffer secondary lactose intolerance. 


\section{ORIGINAL ARTICLE}

A genotyping variant C/T-13910 with LP or LNP was used as a reliable test to detect hypolactasia. Genotyping lactase deficiency was chosen as the most suitable method of selective screening for hypolactasia.[5,12,14]

The high prevalence of a genotype of lactose intolerance among the Uzbek population belonging to the Turkish group of peoples living in Central Asia is probably linked to a weak penetration in this territory of the mutated alleles $\mathrm{C} / \mathrm{T}$ and $\mathrm{T} / \mathrm{T}$ of LCT gene.[15,16]

As shown by previous studies, despite the high frequency of the genotype C/C- 13910, 78\% of the sample Uzbek population consumed fresh milk in their diet, mostly in small amounts. Fourteen of 81people (17.3\%) with the genotype C/C-13910 reported symptoms of GI disorders after drinking fresh milk $(\mathrm{p}<0.05)$. The most commonly found symptoms were gas or bloating in the abdomen and diarrhea.[17]

However, most people with the established genotype C/C-13910 consumed 100 to $250 \mathrm{ml}$ of fresh milk a day (Equivalent to an intake of $12.5 \mathrm{gm}$ of galactose) without milk intolerance.[13,8-22] The majority of Uzbeks tolerate the use of dairy products, regardless of affiliation to the genotype of C/C or $\mathrm{C} / \mathrm{T}-13910$ ( $\mathrm{p}>0.05$ ) and use dairy products like katik(yogurt) and suyzma(curd) daily or several times a week.

Six study participants reported gastrointestinal symptoms after consuming milk products. All of them are carriers of the genotype C/C-13910. In this 3rd participants of study indicating intolerant of dairy products continued to use yogurt from time to time.

Many dairy products contain lactose in the same amount as milk or slightly less than in milk. It should also be borne in mind that the sour milk products, especially cheese and dry milk products are made from a large amount of milk and is a milk concentrate.[2,23]

Often, affected individuals have difficulty digesting fresh milk but can eat certain dairy products such as cheese or yogurt without discomfort. These foods are made using fermentation processes that break down much of the lactose in milk.[11,24,28] The way lactose in these products is digested is of interest to explore. The researchers gave the following evidence for better absorption of lactose in dairy products.

\section{Among them are the following reasons:}

Active microbial $\beta$-galactosidase in bacteria-containing fermented or unfermented milk products survives gastric passage and is released by bile salts into the small intestine, where it supports lactose digestion.[29,30]

Delaying gastric emptying and slowing intestinal transit prolongs the action of residual $\beta$ galactosidase in the small intestine and decreases the osmotic load of the lactose.[31,32]

Short-term and long-term ingestion of lactose and bacteria in the fermented milk product may affect the intestinal $\mathrm{pH}$ and other variables of the intestinal milieu, the intestinal micro flora, lactose fermentation, or the sensitivity of the subject to gastrointestinal disorders and may thus alleviate symptoms of lactose intolerance or other gastrointestinal disorders.

Although the organisms that make up the live cultures in yogurt are recognized as having functional lactase activity and as contributing to the digestion of lactose, their survival in the gastrointestinal tract is short. ${ }^{[11,29,33]}$

Researches of the intestinal micro flora in lactose digestion indicate that lactose digestion in LNP and gastrointestinal well-being can be significantly improved if a milk product contains active microbial $\beta$-galactosidase. The bacteria need not be alive but intact cell walls are required to act as a mechanical protection of the enzyme during gastric passage.[26,27,30,31,34-36] 


\section{ORIGINAL ARTICLE}

The evidence is that the prolonged ingestion of lactose causes changes in colonic bacterial metabolism, resulting in a more efficient microbial carbohydrate digestion and the decrease of gastrointestinal symptoms.[37-39]

Although many probiotic strains have some lactase activity, they normally promote lactose hydrolysis in the small intestine less effectively than do conventional yogurt cultures. For example, bile-salt tolerant lactobacilli, like some strains of Lactobacillus acidophilus, hardly increase lactose digestion and seem to be unable to release $\beta$-galactosidase into the small intestine. ${ }^{[40]}$ The greater tolerance of lactose from yogurt among lactose-intolerant subjects may be due to the lactase activity of yogurt cultures. ${ }^{[41,42]}$

In a study by Savaiano D A et al.[26] a series of breath hydrogen tests was used as well as a subjective assessment to ascertain whether subjects who were identified as lactose-intolerant digested and absorbed lactose in pasteurized yogurt, cultured milk(buttermilk), and sweet acidophilus milk. Pasteurized yogurt was better digested and absorbed than lactose in buttermilk and acidophilus milk.

This subjective feeling of people with lactose intolerance when consuming yogurt was better than with the use of milk. Studies based on using breath hydrogen measurement indicate a better absorption of the lactose of yogurt compared to the lactose of buttermilk and sweet acidophilus milk.

At the same time lactase activity and the number of surviving lactic acid bacteria (LAB) were significantly reduced when the yogurt was pasteurized. The process of heating fermented milk also adversely affects the activity of lactase, which indicates that lactose yogurt, which contains living and active LAB, is better absorbed in persons with LNP in comparison with lactose found in heat-treated fermented milks.[43]

Lactose content also varies with the duration of storage after fermentation. The enhanced digestion of lactose is explained partly by the improved lactase activity after yogurt ingestion and partly by other enzymatic functions, such as the activity of the lactose transport system (Permease) that allows lactose to enter the probiotic cell.[44]

CONCLUSION: Despite the high prevalence of lactase deficiency in the Uzbek population, Uzbeks tolerate and regularly consume dairy products well. Regular consumption of fermented milk products in the diet of the Uzbek population is likely to compensate for the rare use of milk and helps with the intake of calcium and other nutrients contained in milk.

\section{REFERENCES:}

1. Heyman MB. Lactose intolerance in infants, children, and adolescents. Pediatrics. 2006; 118: 1279-1286

2. Scrimshaw NS, Murray EB. The acceptability of milk and milk products in populations with a high prevalence of lactose intolerance. The American journal of clinical nutrition.1988; 48:1079-159.

3. Tortora GJ, Derrickson BH. Principles of anatomy and physiology. 13th Edition. JohnWiley \& Sons. 2012.

4. Swallow DM. Genetics of lactase persistence and lactose intolerance. Annual review of genetics.2003; 37: 197-219.

5. Enattah NS, Jensen TGK, Nielsen M, Lewinski R, Kuokkanen M, Rasinpera H et al. Independent introduction of two lactase-persistence alleles into human populations reflects different history of adaptation to milk culture. The American Journal of Human Genetics. 2008; 82: $\quad$ 57-72.

6. Wray GA. The evolutionary significance of cis-regulatory mutations. Nature Reviews Genetics.2007;8:206-216. 


\section{ORIGINAL ARTICLE}

7. Longstreth GF, Thompson WG, Chey WD, Houghton LA, Mearin F, Spiller RC. Functional bowel disorders. Gastroenterology.2006; 130: 1480-1491.

8. Suarez FL, Savaiano DA, Levitt MD. A comparison of symptoms after the consumption of milk or lactose-hydrolyzed milk by people with self-reported severe lactose intolerance. New England Journal of Medicine. 1995; 333: 1-4.

9. Khabarova Y, Tornianen S, Tuomisto S, Järvelä I, Karhunen P, Isokoski M et al. Lactase nonpersistent genotype influences milk consumption and gastrointestinal symptoms in Northern Russians//BMC gastroenterology.2011; 11:124.

10. Simoons FJ. Primary adult lactose intolerance and the milking habit: a problem in biologic and cultural interrelations. The American journal of digestive diseases.1970; 15:695-710.

11. de Vrese M, Stegelmann A, Richter B, Fenselau S, Laue Ch, Schrezenmeir J. Probioticscompensation for lactase insufficiency. The American journal of clinical nutrition.2001;73:421429

12. Tishkoff SA, Reed FA, Ranciaro A, Voight BF, Babbitt CC, Silverman JS et al. Convergent adaptation of human lactase persistence in Africa and Europe. Nature genetics.2007; 39: 31-40.

13. Lember M, Torniainen S, Kull M, Kallikorm R, Saadla P, Rajasalu T et al. Lactase non-persistence and milk consumption in Estonia. World journal of gastroenterology.2006; 45: 7329-7331.

14. Almon R, Patterson E, Nilsson TK, Engfeldt P and Sjöström M. Body fat and dairy product intake in lactase persistent and non-persistent children and adolescents. Food \& nutrition research. 2010;54 doi:10.3402/fnr.v54i0.5141

15. Hussin J, Nadeau P, Lefebvre JF and Labuda D. Haplotype allelic classes for detecting ongoing positive selection. BioMedCentral bioinformatics.2010;11:doi:10.1186/1471-2105-11-65

16. Bersaglieri T, Sabeti PC, Patterson N, Vanderploeg T, Schaffner SF, Drake JA et al. Genetic signatures of strong recent positive selection at the lactase gene. The American Journal of Human Genetics.2004; 74:1111-1120.

17. Kasimov S, \& Lember M. Adult type hypolactasia in an ethnic Uzbek population. International Journal of Health and Nutrition.2013; 4: 46-49.

18. Suarez FL, Savaiano DA, Levitt MD. A comparison of symptoms after the consumption of milk or lactose-hydrolyzed milk by people with self-reported severe lactose intolerance New England Journal of Medicine. 1995;333:1-4

19. Yoshida Y, Sasaki G, Goto Sh, Yanagiya Shl and Takashina K. Studies on the etiology of milk intolerance in Japanese adults. Gastroenterologia Japonica.1975; 10:29-34.

20. Qiao R, Huang C, Du H, Zeng G, Li L, Ye S. Milk consumption and lactose intolerance in adults. Biomed Environ Science.2011; 24: 512-7.

21. Torniainen S, Torniainen S, Hedelin M, Autio V, Rasinperä H, Klint A et al. Lactase persistence, dietary intake of milk, and the risk for prostate cancer in Sweden and Finland. Cancer Epidemiology Biomarkers \& Prevention.2011; 24:956-961.

22. Raja AH Kuchay, Mumtaz Anwar, Babu R. Thapa, Akhtar Mahmood and Safrun Mahmood. Correlation of G/A -22018 single-nucleotide polymorphism with lactase activity and its usefulness in improving the diagnosis of adult-type hypolactasia among North Indian children. Genes Nutrition.2013; 8: 145-151.

23. Savaiano DA, \& Levitt MD. Milk intolerance and microbe-containing dairy foods. Journal of dairy science.1987; 70:397-406. 


\section{ORIGINAL ARTICLE}

24. Ingram CJ, Mulcare CA, Itan Y, Thomas MG \& Swallow DM. "Lactose digestion and the evolutionary genetics of lactase persistence". Human Genetics.2009; 124: 579-91.

25. Martini MC, Smith DE, Savaiano DA. Lactose digestion from flavored and frozen yogurts, ice milk, and ice cream by lactase-deficient persons. American Journal of Clinical Nutrition 1987; 46:63640.

26. Savaiano DA, Abou E, Anouar A, Smith DE, Levitt MD. Lactose malabsorption from yogurt, pasteurized yogurt, sweet acidophilus milk, and cultured milk in lactase-deficient individuals. American Journal of Clinical Nutrition.1984; 40:1219-23.

27. Dewit O, Pochart P, Desjeux J-F Breath hydrogen concentration and plasma glucose, insulin and free fatty acid levels after lactose, milk, fresh or heated yogurt ingestion by healthy young adults with or without lactose malabsorption. Nutrition.1988;4:131-135

28. Rosado JL, Solomons NW, Allen LH. Lactose digestion from unmodified, low-fat and lactosehydrolyzed yogurt in adult lactose-maldigesters. European journal of clinical nutrition.1992; 46:61-67.

29. Noh DO, Gilliano SE. Influence of bile on $\beta$-galactosidase activity of component species of yogurt starter cultures. Journal of dairy science. 1994; 77: 3532-3537.

30. Gilliland SE, Kim HS Effect of viable starter culture bacteria in yogurt on lactose utilization in humans. Journal of Dairy Science. 1984; 67: 1-6.

31. Marteau P, Flourie B, Pochart P, Chastang C, Desjeux JF, Rambaud JC et al. Effect of the microbial lactase(EC 3.2.1.23) activity in yoghurt on the intestinal absorption of lactose: an in vivo study on lactase-deficient humans. British Journal of Nutrition. 1990; 64: 71-79.

32. Vesa TH, Marteau PR, Briet FB, Boutron-Ruault M-C, Rambaud JC. Raising milk energy content retards gastric emptying of lactose in lactose-intolerant humans with little effect on lactose digestion. The Journal of nutrition.1997; 127:2316-2320.

33. Guerin-Danan C, Chabanet C, Pedone C, Popot F, Vaissade P, Bouley C et al. Milk fermented with yogurt cultures and Lactobacillus casei compared with yogurt and gelled milk: influence on intestinal microflora in healthy infants. The American journal of clinical nutrition.1998; 67: 111117.

34. McDonough FE, Hitchins AD, Wong NP, Wells P, Bodwell CE. Modification of sweet acidophilus milk to improve utilization by lactose-intolerant persons. The American journal of clinical nutrition.1987; 45: 570-574.

35. Varela-Moreiras G, Antoine JM, Ruiz-Roso B, Varela G. Effects of yogurt and fermented-thenpasteurized milk on lactose absorption in an institutionalized elderly group. Journal of the American College of Nutrition.1992; 11: 168-171.

36. Lerebours E, N'Djitoyap Ndam C, Lavoine A, Hellot MF, Antoine JM, Colin R. Yogurt and fermented-then-pasteurized milk: effects of short-term and long-term ingestion on lactose absorption and mucosal lactase activity in lactase-deficient subjects. The American journal of clinical nutrition.1989; 49: 823-827.

37. Florent C, Flourie B, Leblond A, Rautureau M, Bernier JJ, J C Rambaud et al. Influence of chronic lactulose ingestion on the colonic metabolism of lactulose in man(an in vivo study). Journal of Clinical Investigation.1985; 75:608.

38. Flourié B, Briet F, Florent C, Pellier P, Maurel M, Rambaud JC et al. Can diarrhea induced by lactulose be reduced by prolonged ingestion of lactulose? The American journal of clinical nutrition.1993; 58: 369-375. 


\section{ORIGINAL ARTICLE}

39. Ito M, Kimura M. Influence of lactose on faecal microflora in lactose maldigesters. Microbial ecology in health and disease.1993; 6: 73-76.

40. McDonough FE, Hitchins AD, Wong NP, Wells P, Bodwell CE. Modification of sweet acidophilus milk to improve utilization by lactose-intolerant persons. The American journal of clinical nutrition.1987; 45: 570-574.

41. Arrigoni E, Pochart P, Flourie, Marteau P, Franchisseur C, Rambaud J. Does a prolonged lactose ingestion induce clinical and colonic metabolism adaptations in lactose intolerant subjects? Gastroenterology.1992; 102: A197.

42. Guerin-Danan C, Chabanet C, Pedone C, Popot F, Vaissade P, Bouley C et al. Milk fermented with yogurt cultures and Lactobacillus casei compared with yogurt and gelled milk: influence on intestinal microflora in healthy infants. The American journal of clinical nutrition.1998; 67: 111117.

43. Shermak MA, Saavedra JM, Jackson TL, Huang SS, Bayless TM, Perman J A. Effect of yogurt on symptoms and kinetics of hydrogen production in lactose-malabsorbing children. The American journal of clinical nutrition.1995; 62: 1003-1006.

44. Taranto MP, de Valdez GF, \& Perez-Martinez G. Evidence of a glucose proton motive forcedependent permease and a fructose phosphoenolpyruvate: phosphotransferase transport system in Lactobacillus reuteri CRL 1098. FEMS microbiology letters.1999; 181: 109-112.

\begin{tabular}{|c|c|}
\hline $\begin{array}{c}\text { Genotype of C/T- } \\
\mathbf{1 3 9 1 0} \text { variant }\end{array}$ & $\begin{array}{c}\text { Frequency } \\
\text { (\%) }\end{array}$ \\
\hline C/C & 81 \\
C/T & 19 \\
T/T & 0 \\
\hline \multicolumn{2}{|c|}{ arable I: Frequency of C/T-13910 variants in } \\
\hline
\end{tabular}

\begin{tabular}{|c|c|c|c|c|}
\hline Genotype & $\begin{array}{c}\text { C/C-13910 } \\
\text { N=81 }\end{array}$ & $\begin{array}{c}\text { C/T-13910 } \\
\text { N=19 }\end{array}$ & $\begin{array}{c}\text { T/T- } \\
\mathbf{1 3 9 1 0}\end{array}$ & $\begin{array}{c}\text { Total } \\
\text { N=100 }\end{array}$ \\
\hline \multirow{2}{*}{ *Not dairy consumption } & $3(3.7)$ & & & \\
Daily & $24(29.6)$ & $6(31.5)$ & 0 & 3 \\
Several days a week & $48(59.3)$ & $13(68.4)$ & 0 & 30 \\
Several days a month & $4(4.9)$ & $2(10.5)$ & 0 & 6 \\
** Symptoms from dairy & $6(7.4)$ & 0 & 0 & 6 \\
intolerance & \multicolumn{4}{|c|}{ Table II: Frequency consumption of dairy products (\%) and intolerance to dairy } \\
products, comparing with the different variants of the genotype C/T-13910 \\
\hline
\end{tabular}

$* \mathrm{p}>0.05$ vs C/C-13910 and C/T-13910 among those who consume dairy products; ${ }^{* *} \mathrm{p}>0,05$ vs C/C-13910 and C/T-13910 who have intolerance symptoms to dairy products. 


\section{ORIGINAL ARTICLE}

\section{AUTHORS:}

1. Sharaf Kasimov

2. Gulchehra Nazarova

3. Dania Kasimova

4. Zebo Yunusova

5. Movluda Rakhmatova

\section{PARTICULARS OF CONTRIBUTORS:}

1. Associate Professor, Department of Continuing Medical Education for General Practitioners of the Tashkent Institute of Postgraduate Medical Education, Uzbekistan.

2. Associate Professor, Department of Continuing Medical Education for General Practitioners of the Andijan Medical Institute, Uzbekistan.

3. Assistant, Department of Continuing Medical Education for General Practitioners of the Tashkent Institute of Postgraduate Medical Education, Uzbekistan.

FINANCIAL OR OTHER COMPETING INTERESTS: None
4. Assistant, Department of Continuing Medical Education for General Practitioners of the Andijan Medical Institute, Uzbekistan.

5. Assistant, Department of Continuing Medical Education for General Practitioners of the Andijan Medical Institute, Uzbekistan.

\section{NAME ADDRESS EMAIL ID OF THE CORRESPONDING AUTHOR:}

Sharaf Kasimov, 100007, Republic Uzbekistan, Tashket, Parkenskaja str., 51.

E-mail: uzgpmail@gmail.com

Date of Submission: 08/08/2015. Date of Peer Review: 12/08/2015. Date of Acceptance: 15/10/2015. Date of Publishing: 26/10/2015. 